\title{
Dansk \\ Universitetspædagogisk Netværk (DUN) - før, nu og fremover
}

Thomas Harboe, formand, Dansk Universitetspeedagogisk Netverk (DUN)

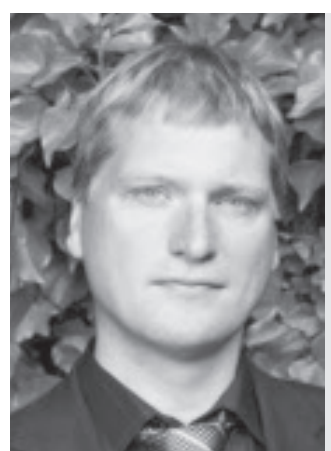

Thomas Harboe har arbejdet med universitetspædagogik på Det Samfundsvidenskabelige Fakultet, Københavns Universitet, siden foråret 1998. Han har siddet i DUNs bestyrelse siden 2001 , først som kasserer og siden 2005 som formand. I dag er han $\mathrm{i}$ gang med et ph.d.-projekt om studieledelse, der er et samarbejdsprojekt mellem de to samfundsvidenskabelige fakulteter på henholdsvis Københavns Universitet og Syddansk Universitet. Han arbejder desuden med at etablere en ny universitetspædagogisk enhed på Det Samfundsvidenskabelige Fakultet under Syddansk Universitet.

I år fylder DUN 15 år og står som et levende bevis for det høje niveau inden for den danske universitetspædagogiske forskning og debat. Jeg vil i denne artikel fortælle historien om DUN samt tegne omridset af den samfundsudvikling, hvor den danske universitetspædagogik finder sted. Min hovedpointe er, at der er brug for DUN, men at DUN også har brug for at tilpasse sig de nye tider.

\section{DUNs første år}

DUN startede som et græsrodsinitiativ med en række pædagogiske ressourcepersoner og ildsjæle blandt initiativtagerne. Den stiftende generalforsamling blev holdt den 13. juni 1994 på Københavns Universitet.

Professor Per Fibæk Laursen, der i en periode i slutningen af 90'erne var formand for DUN, har skrevet en artikel om DUNs tidlige historie, og han peger her på to begivenheder, der havde særlig betydning for oprettelsen af DUN, nemlig etableringen af Eva- lueringscentret i 1992 samt indførelsen af obligatorisk pædagogisk uddannelse af universiteternes adjunkter i 1993 (Fibæk Laursen, 2003).

Evalueringscentret (EVA), der blev oprettet som en selvstændig enhed under Undervisningsministeriet, var fra starten tænkt som en ekstern evalueringsinstans. ${ }^{1}$ Fibæk beskriver i sin artikel, at dannelsen af EVA blev "modt med en betydelig skepsis $i$ universitetsverdenen, fordi det blev set som en udefrakommende indblanding $i$ universiteternes interne anliggende" (Fibæk Laursen, 2003), og at DUN skulle være et slags modsvar til dette.

Den anden vigtige begivenhed, som Fibæk peger på, var, at der i 1992 blev lovgivet om det såkaldte adjunktpædagogikum. Dette blev ifølge Fibæk set som "et gennembrud for universitetspedagogikken, fordi det for forste gang blev et obligatorisk krav til faste universitetslarere, at man skulle have en podagogisk uddannelse" (Fibæk Laursen, 2003). Adjunktpædagogikum har eksisteret siden da i mange forskellige versioner. Det har været en ressource- og tidskrævende opgave for universiteterne at udbyde adjunktpædagogikum. Men det har på den anden side utvivlsomt givet universitetsundervisningen et generelt kvalitetsløft.

\section{Universitetspædagogik - en kompleks og konfliktfyldt virkelighed}

Fibæks beskrivelse af de begivenheder, der forte til dannelsen af DUN i starten af 90'erne, demonstrerer, at DUN er et produkt af samtiden og til tider kan anskues som en direkte reaktion på aktuelle politiske tendenser. På den ene side synes der noget uundgåeligt over den udvikling, der fører til stadigt stigende krav om at udvikle og evaluere universitetspædagogikken. På den anden side er der behov for modsvar og alternativer til denne udvikling. Det er derfor nærliggende at se lidt nærmere på nogle af de konflikter og debatter, 
der har præget universitetspædagogikken siden starten af 90'erne.

Én af konflikterne handler om, at universitetsfolk på den ene side står med en udtalt modvilje og irritation over for det, de ser som utidig indblanding udefra. Politikernes og mediernes ofte meget ensidige kritik opfattes som en mistillidserklæring til den måde, universiteterne varetager arbejdet med at kvalitetssikre uddannelserne og undervisningen. På den anden side står medierne og politikerne, der er presset af et komplekst samfund, og som konstant fristes til at gribe til stadigt flere love $\mathrm{i}$ et forsøg på styre og kvalitetssikre uddannelsesområdet. Den generelle tendens i Danmark er et tiltagende krav om kontrol, styring og dokumentation. Tendensen, der i øvrigt er et veldokumenteret internationalt fænomen, risikerer at kvæle ansattes professionelle engagement og blive en evig kilde til stress i samfundet. Enkelte politikere taler om behovet for en "tillidsreform", hvor politikerne overlader kontrollen og kvalitetssikringen til de lokale faglige miljøer. Faktisk er der bred enighed i folketinget om, at lovgivningsarbejdet har taget overhånd, men ikke desto mindre viser en aktuel undersøgelse fra Dansk Erhverv, ${ }^{2}$ at der aldrig før har været vedtaget så mange nye love og bekendtgørelser som under den nuværende regering. ${ }^{3}$

En ting er sikkert: Universitetspædagogikken er ikke længere et internt universitetsanliggende, men et emne, som lovgiverne interesserer sig varmt for. Lad mig nævne nogle eksempler. I 2005 afskaffede regeringen gruppeeksaminer. I 2007 vedtog folketinget nye regler for specialerne. Formålet var primært at gøre noget ved de lange gennemførelsestider, men reglerne havde også en række konsekvenser for, hvordan specialevejledningen fremover kunne udøves. I $2008 \mathrm{blev}$ et nyt merit-ankenævn nedsat, primært for at fremme mobiliteten mellem universiteterne. Nu skulle det være lettere at få overført beståede eksaminer fra studie til studie. Og her i starten af 2009 diskuterer politikerne et forslag om en ombudsmandsordning på universiteterne, der skal give de studerende en uafhængig klageinstans. Alle fire eksempler demonstrerer, hvordan lovgiverne i Danmark regulerer nye områder, der traditionelt har været opfattet som interne universitetsanliggender.

\section{Revisioner af stillingsstrukturen}

Lovgiverne har også flere gange revideret den såkaldte Stillingsstruktur, der regulerer ansættelseskriterier og karriereforløb på universiteterne. Revisionerne er interessante, fordi de bevidner, hvordan kravene om pædagogiske meritter i en universitetskarriere bølger frem og tilbage:

- Stillingsstrukturen fra $1993^{4}$ interesserer sig primært for ansættelsesvilkår, lønvilkår, prøvetider og opsigelsesmuligheder. Her finder man ingen særlige krav om undervisningskvalifikationer.
- Revisionen af Stillingsstrukturen i $2000^{5}$ fremhæver »ligestilling af forskning og undervisning og en generel opgradering af uddannelsesmassige og pedagogiske kvalifikationer som en primær målsætning, hvilket var temmelig revolutionerende selv set $\mathrm{i}$ forhold til nuværende forhold. Under kvalifikationskravet til en lektor står, at undervisnings- og forskningskvalifikationer »indgar tilsammen med en hovedvagt $i$ helhedsvurderingen «. Ansøgeren skal desuden kunne "fremlagge dokumentation for sine undervisningsmassige kvalifikationer eller anden form for materiale, som kan danne grundlag for en vurdering af ansogerens undervisningsmassige/predagogiske niveau. "Portfolio-tanken, at ansøgere skal kunne skriftligt dokumentere undervisningskvalifikationer, har fundet vej ind i Stillingsstrukturen.

- I revisionen fra $2004^{6}$ finder man ikke længere ordet »ligestilling ", hverken direkte eller indirekte. Formuleringen om hovedvægte fra 2000 er nu ændret til en mere blød hensigtserklæring: "Voggtningen mellem de forskellige opgaver kan variere over tid. «Dokumentationskravet fra 2000 er også formuleret mere upræcist: "Anscettelse forudscetter, at ansegeren har dokumenteret kvalifikationer som er forudsat for den enkelte stilling. " og der er nu tilføjet en ny bestemmelse om at "Universitetet kan $i$ scerlige tilfoelde fravige kravet om, at stillingen skal omfatte undervisningsopgaver . I stedet finder man nye områder tilføjet i listen over kvalifikationskrav for lektorstillingen såsom »videnudveksling med samfundet« og »deltagelse i den offentlige debat».

- I den seneste revision fra $2007^{7}$ er formuleringen fra 2004 skærpet til "Universitetet kan i scerlige tilfaelde og $i$ begrenset omfang fravige kravet om, at stillingen skal indeholde undervisningsopgaver" (min understregning). Jeg tolker dette som et klart signal til universiteterne om at ikke misbruge muligheden for at ansætte videnskabeligt personale $i$ andre stillingskategorier end adjunkt, lektor og professor, hvor der indgår undervisningsforpligtelser. Desuden er dokumentationskravet fra 2000 skærpet til "Det forudsattes, at ansegere har modtaget supervision og peedagogisk opkvalificering og har modtaget en positiv skriftlig vurdering af sine undervisningsmassige kvalifikationer". Det er nu klarere, hvad indholdet i dokumentationen bør være.

\section{Love vækker frustrationer og debat}

De mange nye love er ikke alle steder lige populære, hvis man skal bedømme det ud fra de debatter, der kører i medierne. Lige nu kører en underskriftindsamling mod Universitetsloven fra 2003/2005, der »afskaffede demokratiet" på universiteterne. Underskriftindsamlingen, der i skrivende stund har omkring 6500 underskrifter, kæmper blandt andet for "Indførelse af en styreform på universiteterne, der bygger på principper om 
selvstyre og akademisk frihed. Dette indebarer en styrelsesordning, der tildeler reel magt over universitetets anliggender til demokratisk valgte organer med reprosentation fra alle grupper af ansatte og studerende. ${ }^{8}$ Universitetsloven skal revideres $\mathrm{i}$ år, og der forventes en ophedet debat om forskningsfrihed og selvstyre.

Omvendt findes der også en del universitetsansatte, der hilser de nye love velkomne. Der har jo unægtelig været behov for at reformere universitetsledelsen væk fra valgte ledere, der modvilligt stillede op til ledelsesfunktionerne, fordi "det var deres tur", og typisk havde vanskeligt ved at træffe og gennemføre beslutninger pga. et modvilligt VIP-kollegium. Måske ikke et udbredt fænomen på alle danske institutter, men givetvis et fænomen, som mange kan nikke genkendende til.

Politikernes fokus på gennemførelsestider og frafald har heller ikke været helt ubegrundet. Hvordan har universiteterne for eksempel kunne leve med en gennemsnitlig kandidatalder på næsten 30 år? Hvordan har universiteterne kunnet retfærdiggøre frafald på 30-50 procent af en studieårgang? Og hvorfor har universiteterne ikke selv gjort noget effektivt ved specialesumpen, ${ }^{9}$ hvor det på mange studier var mere reglen end undtagelsen, at det tog mellem 1 og 3 år at skrive den afsluttende kandidatafhandling, der ifølge studieordningerne burde kunne skrives på $1 / 2$ å?

Nuvel, det er tænkeligt, at nævnte tal ikke er repræsentative for alle universiteter og studier. Der er utvivlsomt store forskelle fra fag til fag. Men i mine øjne har universiteterne reelt sovet $\mathrm{i}$ timen på udvalgte områder. Den universitetspædagogiske udvikling synes til tider at være mest drevet af "udefrakommende« initiativer, og ofte har de største reformer været et resultat af dårlig medieomtale og politisk fokus på området. Når jeg ser tilbage på de seneste 15 års universitetspædagogiske udvikling virker det, som om universiteterne har været mere reaktive end proaktive!

Men min fornemmelse fortæller også, at denne tendens for alvor er ved at vende nu. Universiteterne er kommet mere på banen inden for det universitetspædagogiske område. Der formuleres nu pædagogiske politikker på de fleste universiteter. Problemet nu er måske snarere en for høj grad af detailstyring fra lovgivernes og ministeriets side, jf. førnævnte behov for en tillidsreform. I dag er spørgsmålet måske snarere, om lovgiverne skal holde op med at ordinere enhedsmedicin til helt forskellige patienter - herunder også til de patienter, der ikke er syge.

\section{Fra græsrodsbevægelse til en velorganiseret forening}

Det er inden for denne ophedede universitetsdebat, at DUN nu har eksisteret i 15 år. DUN oplevede en stærk tilslutning i de første år i 90'erne med 3-4 konferencer per år, og ofte med deltagerantal på over 100. Imidlertid var det, som om luften gik ud af ballonen hen mod slutningen af 90'erne. Den årlige DUN-konference i 2000 blev aflyst på grund af for få tilmeldte. Og der var seriøse diskussioner ved generalforsamlingen $\mathrm{i}$ april 2001 om at nedlægge DUN.

Medicinen for DUN var at reetablere organisationen. DUN fik helt nye vedtægter i 2001, der på mange måder var mere operationelle og forståelige i forhold til de tidligere. Der blev brugt penge på en helt ny hjemmeside med en opdateret medlemsliste. Økonomien blev trimmet, og der blev formuleret en forretningsorden for bestyrelsesarbejdet. Alt sammen tiltag, der ikke er synlige for de fleste. Ikke desto mindre er jeg overbevist om, at netop dette arbejde sikrede DUNs fortsatte eksistens. DUN gik fra at være en meget løst organiseret græsrodsbevægelse til at være en mere veldefineret forening med målsætninger og en fast mødestruktur. Og organiseringsarbejdet fortsæetter her i 2009 med etablering af et DUN-sekretariat, der kan støtte bestyrelsen i arbejdet med hjemmeside, medlemsregistrering, bogholderi og lign.

I de sidste otte år har DUN oplevet fremgang på alle områder. DUN har i dag en medlemsliste, der tæller omkring 1000 medlemmer, og der kommer hele tiden nye medlemmer til. DUNs mailingliste er i dag det mest brugte medie til annoncering af universitetspædagogiske arrangementer i Danmark. Og der afholdes årligt en universitetspædagogisk konference, hvor omkring 150 engagerede universitetsfolk mødes to dage. Hertil kommer, at DUN udgav sit eget tidsskrift første gang i marts 2006, hvilket på mange måder var »toppen af kransekagen«. ${ }^{10}$

\section{Dansk Universitetspædagogisk Tidsskrift (DUT)}

Det var kun muligt for DUN at påtage sig opgaven med at udgive et tidsskrift, fordi kompetente universitetsfolk ville kaste deres tid og ressourcer ind i redaktionsarbejdet. Men en anden vigtig forudsætning var, at DUNs økonomi og organisation var trimmet og redifineret

Tidsskriftet er på cirka 60 sider og udkommer med to numre årligt. Ambitionen er at kunne tiltrække artikler på et højt fagligt niveau inden for universitetspædagogik. Artikelforfatterne tilbydes peer review, hvilket ikke kun er interessant for forskere og undervisere, der arbejder professionelt med pædagogik, men også for universitetsundervisere inden for andre fag. En peer review artikel i DUT er en god måde at dokumentere pædagogiske kompetencer, og tidsskriftet har derfor også modtaget universitetspædagogiske artikler, der er skrevet af universitetsfolk med vidt forskellige faglige profiler, der spænder fra filosofi og nordisk historie over IT til statskundskab. Herudover er der også plads i tidsskriftet til artikler uden peer review, eksempelvis mere debatterende artikler eller boganmeldelser.

Erfaringerne med de første seks udgivelser har 
været overordentligt positive. Artiklerne har været af høj kvalitet, og tidsskriftet bliver nu trykt i 1200 eksemplarer, der udsendes gratis til DUNs medlemmer samt ledere på universiteterne. Spørgsmålet er, hvor vi skal sætte ambitionsniveauet for udbredelsen af DUT. Til sammenligning udkommer i Norge et tilsvarende universitetspædagogisk tidsskrift »Uniped «11 i 8500 eksemplarer.Vores mål er dog ikke at uddele DUT gratis til alle danske universitetsansatte. DUT skal være et tidsskrift, der aktivt efterspørges og læses.

Tidsskriftet findes i øvrigt også på nettet, ${ }^{12}$ og DUNs bestyrelse diskuterer aktuelt om publiceringsformen fremover skal blive en ren netversion eller om DUN skal holde fast i den trykte version.

\section{Hvem er DUNs målgruppe og hvem bør den være?}

DUN er altså et universitetspædagogisk netværk, men hvem er egentlig netværkets målgruppe? Hvem interesserer sig for universitetspædagogik? Og hvem interesserer sig tilstrekkeligt for universitetspædagogik til at ville deltage aktivt i DUNs arrangementer?

Der er stor forskel på de sidste to spørgsmål. Listen med interessenter er meget lang, hvis kriteriet alene er "interesse for universitetspædagogik «: undervisere, vejledere, studerende, studenterpolitikere, universitetets ledelse, det administrative personale, pædagogiske konsulenter, medierne, folketingspolitikere, lovgivere, ministeriefolk samt diverse erhvervs- og interesseorganisationer. Alle har en mening om universitetspædagogikken, og mange af disse har også reel indflydelse.

Hvis kriteriet derimod er en eller anden form for aktivitet $\mathrm{i}$ forhold til DUN, bliver listen knap så lang. DUN har ganske vist i dag omkring 1000 medlemmer, og blandt disse finder vi mange universitetsundervisere og -ledere. Alle 1000 har aktivt fundet frem til DUNs hjemmeside, tilmeldt sig som medlem og modtager tidsskriftet med posten. Men blandt de cirka 150 personer, der typisk deltager i DUNs arrangementer - som f.eks. den årlige konference - finder vi primært folk, der arbejder professionelt med universitetspædagogik, og især som uddannelsesudviklere.

Det store spørgsmål for DUN er derfor aktuelt, hvorvidt vi skal være tilfredse med at være et netværk for professionelle universitetspædagoger, ildsjæle og tilsvarende pædagogiske ressourcepersoner. Eller om DUN skal forsøge at fă kontakt med alle de mange andre interessentgrupper, der har indflydelse på universitetspædagogik i Danmark. Jeg vil tage spørgsmålet i det følgende ved at knytte nogle kommentarer til fire udvalgte målgrupper.

\section{Uddannelsesudviklere}

Her taler vi om den gruppe af folk, der professionelt arbejder med universitetspædagogik i hverdagen. Nogle hører til blandt det videnskabelige personale med forskningskompetence inden for universitetspædagogik. Der er eksempelvis lektorer og professorer, der er ansat på forskellige typer pædagogiske institutter landet over. Andre er forskellige slags udviklingskonsulenter. Det kan for eksempel være pædagogiske konsulenter, procesvejledere, coaches, studieteknikeksperter, fagreferenter (eksperter i litteratursøgning) og e-læringskonsulenter. Fælles for de fleste er, at de primært arbejder som udviklingsagenter ("educational developers", Land (2004), Handal (2008)) og kun i mindre grad står for selve studenterundervisningen (eller for den sags skyld studieledelsen).

Mange (ikke alle) af disse uddannelsesudviklere arbejder i lokale pædagogiske udviklingscentre, som gennem de seneste tiår er etableret på de fleste fakulteter i Danmark. Der er eksempler på sådanne pædagogiske centre helt tilbage i slutningen af 1960'erne, hvor Københavns Universitet som det første i Norden udbød universitetspædagogiske kurser. Men det var først i 1990'erne at der opstod veletablerede og robuste universitetspædagogiske udviklingscentre i Danmark.

Evalueringsinstituttet (EVA) kortlagde i 2003 de pædagogiske centre på danske universiteter, og ikke overraskende viste denne undersøgelse en stor diversitet (Evalueringsinstituttet, 2003). Der findes centre, der har adjunktpædagogikum som deres største og mest primære opgave, og som typisk kun beskæftiger sig med undervisersiden. Andre centre har både undervisere og studerende som målgruppe. Og atter andre centre beskæftiger sig udelukkende med e-læring.

Størstedelen af centrene følger devisen »lille men effektiv«, mens nogle få er større og følgelig mere ressourcestærke. Der er typisk en meget god energi i disse centre. Størstedelen af den danske universitetspædagogiske litteratur er skrevet af folk, der arbejder i disse centre. Min egen forklaring på disse centres succes er, at de er tæet på deres brugere, og at deres virke ofte er mere pragmatisk og konsulentagtig snarere end distanceret forskning.

\section{Universitetsundervisere}

DUN-konferencerne planlægges og markedsføres altid med håbet om, at en bred vifte af universitetsundervisere tiltrækkes af konferencens emner og keynotespeakere. I det mindste håber man, at underviserne på det lokale universitet, hvor konferencen afholdes, deltager i stort antal. Dette er dog kun lykkedes i begrænset omfang.

Tidsskriftet har som sagt også en ambition om at appellere til universitetsundervisere generelt. Ønsket er at give dem mulighed for at reflektere over - og formidle - egen universitetspædagogisk praksis. Særligt var det tanken, at adjunkter kan bruge tidsskriftet til at dokumentere deres pædagogiske refleksioner, hvilket i 
stigende grad er et krav, hvis man vil gøre sig håb om en universitetskarriere.

Sidstnævnte er til en vis grad lykkedes. Ud af 42 artikler, debatindlæg og anmeldelser i de første 5 numre af DUT er 12 skrevet af såkaldte almindelige undervisere (herunder et par studieledere). Der er dog i mine øjne stadig et stykke vej, før tidsskriftet når de større masser af fastansatte og deltidsansatte universitetslærere, jfr. diskussionen om DUTs oplagsstørrelse tidligere $i$ denne artikel.

\section{Universitetsledelsen}

Universitetsledelserne er i stigende grad blevet kritiseret for ikke at varetage arbejdet med at kvalitetssikre uddannelserne og undervisningen ordentligt. Man møder denne kritik fx i en større undersøgelse udarbejdet af Rigsrevisionen ${ }^{13}$ (2008): „Det er Rigsrevisionens samlede vurdering, at universiteter frem over både kan og bor arbejde mere malrettet og helhedsorienteret med kvaliteten $i$ uddannelserne. «14

Universitetsloven (2005) placerer ansvaret for kvalitetssikring og -udvikling af uddannelserne og undervisningen i studiencevnene. I praksis spiller studielederne her en central rolle, selvom universitetsloven begrænser studielederens ansvar til "i samarbejde med studiencevnet at forestå den praktiske tilretteloggelse af undervisning og af prover og anden bedømmelse, der indgår i eksamen." (Universitetsloven, \18).

Studieledelsen har i det hele taget ikke en nem opgave på universiteterne. En anden dansk undersøgelse (Gleerup \& Dahler-Larsen, 2001) kom med den interessante konklusion, at det videnskabelige personale på universiteterne netop vælger en universitetskarriere ud fra forestillingen om, at universitetet er et sted, hvor ledelsen ikke dominerer hverdagen. Selvledelse synes at være en væsentlig motivationsfaktor blandt det videnskabelige personale. Spørgsmålet om, hvordan man leder medarbejdere, der ikke vil ledes, er nærliggende.

Det samlede indtryk er, at udviklingen fra eliteuniversitet til masseuniversitet har nødvendiggjort en mere klar og entydig ledelse af den pædagogiske udvikling på universiteterne, og at studielederne i stigende grad forventes at kunne sætte en universitetspædagogisk dagsorden. Første skridt mod dette blev taget med den store ledelsesreform i 2005, hvor institutlederne som noget nyt blev ansat/professionaliseret, og hvor magtforholdene mellem studielederne og institutlederne er rykket til sidstnævntes fordel. Men når der er tale om studieledelsen og andre former for ledelse af pædagogisk udvikling, er der antageligt stadig tale om en vis grad af uigennemsigtighed og beslutningsanarkisme. På nogle studier har studielederen en central rolle og kompetence, mens andre studier mere eller mindre eksplicit har uddelegeret ansvaret for pædagogisk udvikling til andre grupper ( $\mathrm{fx}$ fagkoordinatorer, ildsjæle, studienævn m.fl.)
Min pointe er, at udviklingen i retning af mere klar studieledelse kalder på nye ledelsesstrategier og på fokuserede debatter i forskellige kvalificerede ledelsesfora. Internationalt er denne udvikling allerede i fuld gang. En simpel googlesøgning giver 2260 hits på "Higher Educational Management" med links til alle dele af verden. Der er her et oplagt område, hvor DUN kan spille en mere aktiv rolle og tiltrække studieledere, uddannelsesdekaner og tilsvarende centralt placerede beslutningstagere til målrettede arrangementer og dannelse af studieledelsesnetværk.

\section{Politikerne og lovgiverne}

Man gør klogt i ikke at undervurdere, hvilken rolle politikerne og lovgiverne spiller for universitetspædagogikken. De nye specialeregler, der både sigter mod en strammere tidsplanlægning og klarere forventningsafstemning tidligt i specialeforløbet, og det efterfølgende behov for kvalitetssikring af specialevejledningen, er et rammende eksempel på, hvordan de politiske beslutningsprocesser kan være afgørende for, hvilke vilkår det pædagogiske udviklingsarbejde har.

Vejledere og studieledere har $\mathrm{i}$ årevis forsøgt at bekæmpe fænomenet specialesump, og listen af dokumenterede pædagogiske eksperimenter på området er forholdsvis lang. Alligevel er det først med et øget politisk fokus, folketingets vedtagelse af de nye specialeregler gennem ændring af uddannelses- og eksamensbekendtgørelserne i 2007, samt heraf følgende implementering af såkaldte vejledningskontrakter, at universiteterne antageligvis kommer specialesumpen til livs.

Politikere lader sig som bekendt ofte påvirke af medierne, og her har der ikke været mangel på forfærdelige historier om ulykkelige studerende, der var havnet i specialesumpen. Det var efterhånden klart for alle, at der skulle gøres noget.

Men igen virkede det, som om universiteterne ikke havde evnen eller viljen til selv at løse problemet. Faktisk kom opgøret med specialesumpen først for alvor, efter at Globaliseringsrådet, der var et regeringsudvalg med særlig fokus på uddannelse, kom med deres strategirapport den 16. marts 2006. Strategien indeholdt 350 konkrete initiativer, som indebar omfattende reformer af især uddannelser og forskning. Særligt var der en række klare anbefalinger om, at universiteterne skulle gøre noget substantielt ved frafald og gennemførelsestider.

Siden er det gået hurtigt med udviklingskontrakter, strategiplaner og pædagogiske politikker, der alle sætter fokus på gennemførelsestider og frafald. Der er næppe et institut i hele Danmark, som i dag ikke har fokus på gennemførelsestider og frafald. Og specialesumpen er heldigvis snart kun et historisk fænomen. 


\section{DUNs fremtid på kort sigt og lidt længere sigt}

Jeg startede denne artikel med at påstå, at der er brug for DUN, men at DUN også har brug for at tilpasse sig de nye tider. Den første del af min påstand er relativt let at verificere. DUN er utvivlsomt en organisation i fremgang, og der er ikke noget, der tyder på, at denne interesse for DUN bliver mindre. Den anden del - nemlig at DUN har behov for at udvikle sig i tæt samspil med de instanser, der styrer samfundsudviklingen - er for mig at se også relativt klart, i alle fald på længere sigt.

Fibæk skriver i sin artikel om DUNs historie, at der fra starten var »enighed om at danne et så vidt muligt ubureaukratisk netvork af alle, der arbejdede med padagogisk udvikling og uddannelse på højere uddannelser i Danmark, hvad enten det var som fagpadagog, leder eller som underviser, og at arbejdet forst og fremmest skulle foregå ved afholdelse of konferencer og dannelse af mindre grupper til udveksling af erfaring.» (Fibæk Laursen, 2003). Dette formål gælder stadig for DUN. Men når jeg ser på de fire målgrupper, som jeg ovenfor har kort skitseret, vurderer jeg, at DUNs største udfordring må være at komme ud over "Tordenskjolds soldater". DUN har fint fat i fagpædagogerne og andre universitetspædagogiske ildsjæle, men mangler stadig for alvor at kunne nå almindelige undervisere, universitetslederne og for den sags skyld politikerne.

På kort sigt kan DUN sagtens "nøjes" med at fortsætte sine aktiviteter som hidtil. Hjemmesiden, mailinglisten, tidsskriftet og den årlige konference er alle vigtige opgaver, der rigeligt kan holde bestyrelsen og tidsskriftredaktionen aktiveret. Hvis jeg dog skal udpege et enkelt område, som trænger til et løft her og nu, vil jeg pege på en øget inddragelse af forskellige former for online-aktiviteter på DUNs hjemmeside.

På lidt længere sigt kan man forestille sig, at DUN făr en klarere profil med visioner og holdninger. Når jeg ser på de mange debatter og lovtiltag, som jeg har opridset i denne artikel, konkluderer jeg, at universitetspædagogikken i dag tydeligvis er blevet et stærkt politiseret område. Det er derfor en nærliggende tanke, om DUN kan og bør spille en større rolle her. Måske kan DUN fremover spille en endnu mere aktiv rolle med at kvalificere debatten om undervisningskvaliteten i en større offentlighed, gennem medierne og i dialog med begge sider af folketinget. DUN kan forsøge at fă indflydelse gennem lobby-virksomhed, deltagelse i høringer og debat gennem blog og presse o.l. Og DUN bør mere målrettet invitere politikere og andre beslutningstagere til DUN-arrangementer, hvor de kan indgå i debat.

DUN skal også forsøge at komme ind $\mathrm{i}$ en mere direkte dialog med underviserne og lederne på de danske universiteter. Diverse online ressourcer formidlet gennem DUNs hjemmeside kan måske fange almindelige underviseres interesse. Desuden kunne DUN fungere som en slags paraply for de mange forskellige undergrupperinger inden for den danske universitetspædagogik. I efteråret 2008 udsendte DUN-bestyrelsen en invitation til medlemmerne om netværksdannelse med mulighed for støtte gennem DUNs hjemmeside, netværk og økonomi. Etablering af netværksgrupper for studieledere er eksempelvis en oplagt opgave for DUN.

Et tredje område, som jeg her vil fremhæve, er den internationale dimension. DUNs bestyrelse er allerede involveret $i$ et samarbejde med The International Consortium for Educational Development (ICED) ${ }^{15}$, og det har altid været en væsentlig opgave for DUN at kunne tiltrække internationale ressourcepersoner til DUNs arrangementer. Hvad der herudover ligger af opgaver inden for det internationale område er ikke helt klart og diskuteres løbende i bestyrelsen.

Der er med andre ord masser af opgaver for DUN. Ofte er det mere et spørgsmål manglende tid og ressourcer end mangel på gode ideer, der er problemet. Lad mig derfor afslutte med en generel invitation til medlemmerne om at involvere sig i DUNs arbejde på alle niveauer. DUN kan sagtens bruge flere hænder!

\section{Referencer}

Evalueringsinstituttet (2003). Kortlægning af universitetspædagogiske centre i Danmark. I: Dansk Universitetspædagogisk Netværk. Universitetspadagogik år 2003 - inkl. kortlogning af universitetspadagogiske centre i Danmark (s. 19-55). DUN

Fibæk Laursen, P. (2003). Universitetspædagogikkens barndom - og DUNs. I: Dansk Universitetspædagogisk Netværk. Universitetspadagogik ar 2003 - inkl. kortlogning af universitetspadagogiske centre $i$ Danmark (s. 5-12). DUN

Gleerup, J., \& Dahler-Larsen, P. (2001). Mellem strategier og videnstromme. Vurdering af personalepolitiske instrumenter til omstilling og kvalitetsudvikling på universitetsundervisningsområdet. SCKKrapport. Kompetencecentret.

Globaliseringsrådets rapport »Fremgang, fornyelse og tryghed « Rapporten kan hentes på www.globalisering. $\mathrm{dk}$

Handal, G. (2008). Identities of academic developers: Critical friends in the academy? Universitetet i Oslo.

Jensen, T. K. et al. (2006). Dansk Universitetspædagogisk Tidsskrift derfor! Dansk Universitetspeedagogisk Tidsskrift, 1, 1-3

Land, R. (2004). Educational Development, Discourse, Identity and Practice. Open University Press.

Rigsrevisionen (2008). Beretning til statsrevisorerne om sikring og udvikling af kvaliteten af universitetsuddannelserne.

\section{Noter}

1 I dag er "Evalueringscentret blevet til "Evalueringsinstituttet», og de dele, som hører under universitetsloven, er i efteråret 2007 overgået til Akkrediteringsinstitutionen, der er en uafhængig institution underVidenskabsministeriet. Akkrediteringsinstitutionens formål er at sikre og dokumentere kvalitet og relevans af videregående uddannelser ved at foretage en akkreditering af nye og eksisterende uddannelser. For mere information om Akkrediteringsinstitutionen, se www.acedenmark.dk.

2 Se www.danskerhverv.com

3 Professor i statskundskab Jørgen Grønnegård Christensen, Aarhus Universitet, forklarer i dagbladet Jyllands-Posten (24.08.08) den borgerlige regerings rekord i udstedelse af nye love og 
bekendtgørelser således: „Dels at vi fra 2001 har haft en meget rastlos regering, der er voldsomt opsat på at markere handlekraft og vise, at den laver om på tingene. Dels at tempoet $i$ den politiske proces er enormt højt. Der skal ikke mange enkeltsager til for der bliver sat spørgsmålstegn ved, om regler og love ikke skal andres. "

4 Cirkulære Personalestyrelsen nr. 044-93

5 Cirkulære Personalestyrelsen nr. 074-00

6 Cirkulære Personalestyrelsen nr. 064-04

7 Cirkulære Personalestyrelsen nr. 055-07

8 Se http://redfriforsk.blogspot.com/2008/04/underskriftindsamling-2008.html

9 Betegnelsen »specialesump« dækker over det fænomen, at studerende har meget svært ved at få afleveret det afsluttende speciale, og at processen for nogle studerende bliver en psykisk nedbrydende negativ spiral, der bedst kan betegnes som en sump eller kviksand. For yderligere diagnosticering af specialesump, se: Rienecker, Harboe og Stray Jørgensen (2005): Vejledning - en brugsbog for opgave- og specialevejledere på videregående uddannelser. Samfundslitteratur (kapitel 15, s. 247-268)

10 Læs mere om tankerne bag Dansk Universitetspædagogisk Tidsskrift i Jensen (2006)

11 Se http://gammel.uhr.no/informasjon/uniped/omuniped.htm
12 Se www.dun-net.dk

13 Rigsrevisionen er en uafhængig institution under Folketinget, der primært har til opgave at revidere statens regnskaber og være et parlamentarisk kontrolorgan. Omtalte rapport om universiteterne er et eksempel på at Rigsrevisionen undertiden også udarbejder analyseopgaver, der går ud over den snævre definition af regnskabsrevision.

14 Undersøgelsen bygger på et stort datamateriale, herunder spørgeskemabesvarelser fra 200 danske studieledere, hvilket svarer til $90 \%$ af samtlige studieledere for bachelor- og kandidatuddannelserne på universiteterne. Desuden har Rigsrevisionen besøgt alle universiteter og gennemført 45 interview med personer med tilknytning til kvalitetsarbejdet, fx prorektorer, dekaner og administrativt personale. Rigsrevisionens undersøgelse er interessant, fordi den sætter specifikt fokus på studieledelsen, der antages at have en central ledelsesrolle for universiteternes pædagogiske udvikling. Rapporten kommer med en række anbefalinger, $\mathrm{fx}$ bruger rapporten en hel side til et særligt koncept for studielederberetninger, der er udviklet på Copenhagen Business School.

15 Se http://www.osds.uwa.edu.au/iced 